\title{
IMPACT OF EXOGENOUS SHOCKS ON CONSUMPTION APPROXIMATED BY RETAIL TRADE IN CROATIA
}

\begin{abstract}
:
This paper analysis the impact of two different types of exogenous shocks on the consumption, approximated by retail trade in Croatia. The aim of this paper is to show that the crisis caused by financial disturbances and the crisis caused by pandemic have different repercussions on movements of interest rates and further impact on consumption. Banks react differently in a crisis that has no cause in the financial sector compared to the crisis caused by disturbances in the financial and banking market as we had in 2008. Therefore, it will be proven that in crisis of 2020, which is more significant in strength than the crisis in 2009, Croatia has pursued a different economic policy, aimed to retaining jobs and maintaining the level of consumption from prerecession periods. All mentioned emphasizes two facts: 1 . The irrational behavior of the state in a
\end{abstract}

crisis caused by disturbances in the financial and banking sector differs to the state reaction to the crisis caused by a pandemic, that has no financial cause; 2. Fear of negative psychological expectations and falling demand and personal consumption, are the most important components in the GDP structure

\section{Keywords:}

economic crisis; economic policy; consumption; interest rate; real net salary

\section{Author's data:}

${ }^{1}$ Darko, Karič, PhD, darko.karic55@gmail.com, Gredice 124, 10000Zagreb, Croatia

International Journal - VALLIS AUREA • Volume 6 • Number 2 • Croatia, December 2020

UDK 338:66;; DOI 10.2507/IJVA.6.2.2.71 


\section{Introduction}

In the last few months, we have witnessed a new economic crisis that has not been recorded for the last 100 years. The crisis caused by the COVID 19 pandemic, which hit hard the world economy, also had significant consequences on Croatian economy. A new situation, which so far has not been seen in textbooks, caused a crisis of aggregate supply and aggregate demand. If comparing with the recent global crisis of 2008, which spread to the Croatian economy in 2009, significant differences in reaction of monetary and fiscal policy are visible. At the time of the financial crisis, the croatian economy responded with a restrictive monetary policy, i.e. with increasing interest rates. This effect caused a contraction in aggregate demand and deepened the recession until 2014. However, the emerging crisis, which did not come from the financial sector, resulted in expansive monetary policy as well as expansive fiscal policy. Expansive monetary policy at the time of the pandemic was oriented towards decreasing the interest rates, while expansive fiscal policy had a goal to help entrepreneurs who were facing potential layoffs due to the crisis. However, it turned out that despite the measures that came both from the monetary side and from the Government, the negative effects of the crisis were not compensated and there was a decline in a consumption approximated by retail consumption as a key component in the structure of household consumption. The crisis arising from the nonfinancial sector has caused a double contraction on both the supply and demand sides, despite strong monetary and fiscal measures. Domicile consumption and the model of maintaining employment at the pre-crisis level did not have a significant effect on the movement of gross domestic product [GDP]. Thus, the Croatian economy entered a deep recession in Q2 2020 with a decline in GDP of - $15.4 \%$ compared to the same quarter in 2019. That represents the largest quarterly decline in GDP since croatia's independency. In addition to the decline in demand that occurred due to supply constraints, two factors worsened even further; negative psychological expectations and a decline in tourist consumption. The Croatian Government was trying to reduce negative psychological expectations by "pumping" money into the system and maintaining the unemployment rate in the precrisis period. However, they failed. Despite all economic measures, there was a significant decline in consumption aided by a decline in tourism consumption, which has a significant role in the structure of GDP (19.6\% in 2019). Therefore, economic policy creators proposed different measures for 2009 crisis and the 2020 crisis. The foreign exchange reserves of the Central bank and the capital adequacy ratio of banks were still at a high level in 2009, and that could influenced a faster economic recovery. For the recent crisis, this was not the case. The one form of "liquidity trap" was noticed, in which, despite decreasing interest rates and implementation of expansive fiscal policy, the crisis of aggregate supply and demand occurred. All this points show the vulnerability of Croatian economy, which is extremely elastic to exogenous shocks, both to the movement of foreign 
tourist consumption and to the movement of demand in countries, which are our most important foreign trade partners. In the other words, Croatian economy is still consumeroriented with a strong production deficit. Strong production sector represents a long-term generator of economic growth.

\section{Research methods}

In this research, the author will use the monthly series of data of consumption in retail as the best approximation of personal consumption trends for period from January 2007 to September 2020, and the period from July 2013 to September 2020. Personal consumption in the structure of GDP makes about $60 \%$, therefore it is the most important component. In addition to the movement of consumption in retail trade, additional data which are being analyzed: movements of interest rates on household loans, then the movement of real net salary, as well as the movement of foreign tourists' overnights, all by months. The variables of the growth rate of real net salary and the rate of movement of foreign tourists' overnights will be observed from the perspective of control variables while modeling. Source on retail trade trends, real net salary and the number of tourist nights is the Central Bureau of statistics of Croatia, while the source of data on interest rate movements on a monthly basis is the Croatian National Bank.

Based on the analyzed data, the impact of retail consumption due to changes in interest rate movements will be examined. Based on the econometrics program E-views 8.0, the author will test hypotheses about the effect of independent variables on the movement of consumption in retail as a dependent variable. The database will be adapted to test the econometric model of multiple linear regression. The author will try to explain how the economic crisis caused by two different exogenous shocks have different effects on the movements on the economic activities. In addition to econometric testing, descriptive statistics is going to be used as well.

Hypothesis 1: Change in the interest rate on household loans and change of real net salary have no impact on demand growth due to exogenous shock caused in the non-financial sector

The effect of interest rate change on consumption has being analyzed. It is based on examination of the multiple linear regression model of the movements of personal consumption approximated by consumption in retail trade and the movement of interest rates in the period from 2007 to 2020, and the movement of real net salary. Particular emphasis was put on the two crises that has captured us for the past 11 years; the mortgage crisis that occurred in the USA and its effect of transmission on the croatian economy in 2009. Also, it will be analyzed the crisis from 2020 caused by pandemic and economic policy reaction on both crisis. Based on the coefficient of determination and the correlation coefficient, the existence of a relationship between personal consumption measured by consumption in retail trade and the movement of interest rates and real net salary will be examined. All variables in the model will be 
expressed in year-on-year growth rates, on monthly level.

Hypothesis 2: Monetary policy dependents and it is influenced by institutionalism

After analysis of the Hypothesis 1, the author will point out the impartiality in conducting the monetary policy. Based on the collected data on the foreign exchange reserves of the Central bank, author will point out the model of conducting monetary policy in the conditions of various economic crises. Monetary policy was mostly influenced by institutions and did not have its own independence. That point was based on the analysis of the interest rate movements during the 2009 financial crisis and the 2020 crisis.

Hypothesis 3: The number of foreign tourists' overnights has an impact on consumption movements in retail trade

Consumption trends approximated by consumption in retail trade and the number of the foreign tourists' overnights present a significant role. In the econometric model of multiple linear regression, the dependent variable (Y) is the retail trade, while the foreign tourists' overnights (growth rate) and the movements of household interest rates on loans and real net salary present the independent variables. Since croatia is extremely resilient to exogenous shocks, especially to shocks of foreign demand caused by changes in the number of foreign tourists, the author will examine the significance of tourist consumption approximated by the number of overnights on the consumption trends, which is approximated by retail trade.

\section{Economic trends in Croatia between two exogenous shocks}

For the purposes of this paper, author observed a period of two recessions, one that occurred due to the USA mortgage crisis in 2008 and its arrival to Croatian market in 2009, and another crisis caused by an exogenous shock- pandemic. For the purpose of the research, a series of data from January 2007 was taken, as the last relevant year in which Croatia and the world recorded positive economic cycle. Croatia ended the 2007 with a positive real GDP growth rate of $+5.1 \%$. However, after the crisis in the USA which occurred in 2008, Croatia recorded a slowdown in the GDP growth rate of + $1.9 \%$. In the last quarter of 2008, the croatian economy recorded a decline in GDP of $-0,2 \%$. The aggregate decline in personal consumption was $0.6 \%$ in 042007 and that was the first indication of the recession. Due to the low level of productivity and volume of industrial production and a high exposure of the personal consumption variable in the structure of GDP, each element that has effect on consumption has a significant impact on GDP movements. The share of personal household consumption in GDP in 2007 measured by the expenditure method was $59.9 \%$, while the same share in 2019 was $57.0 \%$. At the same time, observing the foreign trade balance and the goods coverage of imports by exports in 2007, it amounted $43.1 \%$, and in 2008 42.1\%, while in 2019 it was $55.0 \%$. The estimation for the first half of 2020 is $57,6 \%$. These indicators show an increasingly 
dominant role of imports and personal consumption in the observed period.

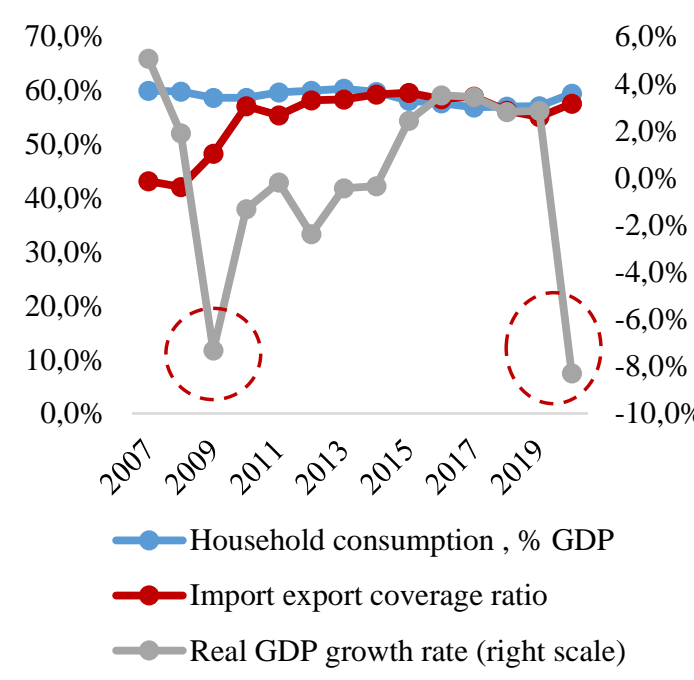

Figure 1. Movements in GDP growth rate, share of household consumption in GDP and coverage of imports by exports from 2007 to 2020 - estimation; source: croatian bureau of statistics, author calculation

Household consumption as a key variable of GDP measured by the expenditure method increased from $40.7 \mathrm{bn}$ HRK in 2019 compared to 2007. At the same period, the coverage of imports by exports increased slightly after the global recession, with imports having slower growth rates compared to exports. After 2011 it was around 57.0\%, and after Croatia entered the European Union, there was a restrengthening of imports and a slower growth rate of exports, which unfavorable affects the foreign trade balance. Figure 1 shows the effect of the recession in 2008 on the share of consumption in the structure of GDP. At observed period the monetary policy had restrictive character, which led to destabilization of consumption due to increase of interest rates. The reaction of banks to the crisis of 2008 was shown as the automatic increase of interest rates, which pushed Croatia even further into the recession, which lasted until 2014. The mentioned monetary policy also had an impact on other variables of GDP. The increase in interest rates had the direct consequences on decreasing investment activity and on decrease of personal consumption. The decline in personal consumption as a generator of economic growth, aided by the decline in investment activity from year to year, has made croatian industry less and less competitive. As the domicile industry became more vulnerable, especially after Croatia entered the European Union, the consequences seen were next: a higher absolute imports compared to exports, which caused import deflation and further distortation of the competitiveness of croatian industry. The accelerated growth rate of imports relative to exports had an impact on the most significant component in the structure of GDP according to the production approach method, where the processing industry makes the backbone of the economy.

$21,0 \%$

$16,0 \%$

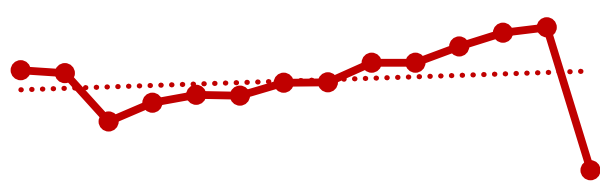

$11,0 \%$

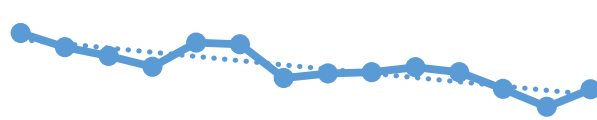

通完 $\longrightarrow$ Manufacturing industry share in GDP

Wholesale and retail trade, transportation,
storage, accommodation and food service
activities share in GDP

Figure 2. Movements in share of processing industry and the share of retail and wholesale trade, i.e.

International Journal - VALLIS AUREA • Volume 6 • Number 2 • Croatia, December 2020 UDK 338:616; DOI 10.2507/IJVA.6.2.2.71 
categories according to the NACE G, G, H, I, from 2007 to 2019; Source: Croatian bureau of statistics, author calculation

Figure 2 shows the declining dominance of the processing industry in the structure of GDP measured by the production method, while the share of retail and wholesale trade, food storage, preparation and serving is increasingly emhasized in the structure. From 2007 to 2013 , the share of the processing industry was around $14.0 \%$, while this trend was declining after 2014, as a result of the entry of cheaper imports and significant pressure on the domicile industry, which was not ready to responde to international competition. However, the share of trade grew significantly in the structure of GDP, which is visible in Figure 2. Also, the gap between the curves of the share of manufacturing (NACE C) in GDP and the share of retail, wholesale [NACE G, H, I] after 2014 became more significant, i.e. the linear trend of trade is increasing, while the linear trend of the processing industry is decreasing. All these indicators show the vulnerability of Croatian economy, as well as the low level of competitiveness. There is a significant decline in personal consumption in retail trade in 2009 compared to 2008, and an even more significant decline in personal consumption in the first half of 2020 . The consumer-oriented economy, which has no foothold in production, is not sustainable in the long run and is significantly exposed to exogenous shocks as can be seen in Figure 2.
Consumption and the interest rate on household loans

An increase in the interest rate according to the theoretical definition results in a decrease in consumption. However, in the emerging crisis of 2020, which did not come from the financial sector, has resulted in a decrease of interest rates and in a decrease in aggregate demand, which has not yet been recorded in modern economic history.

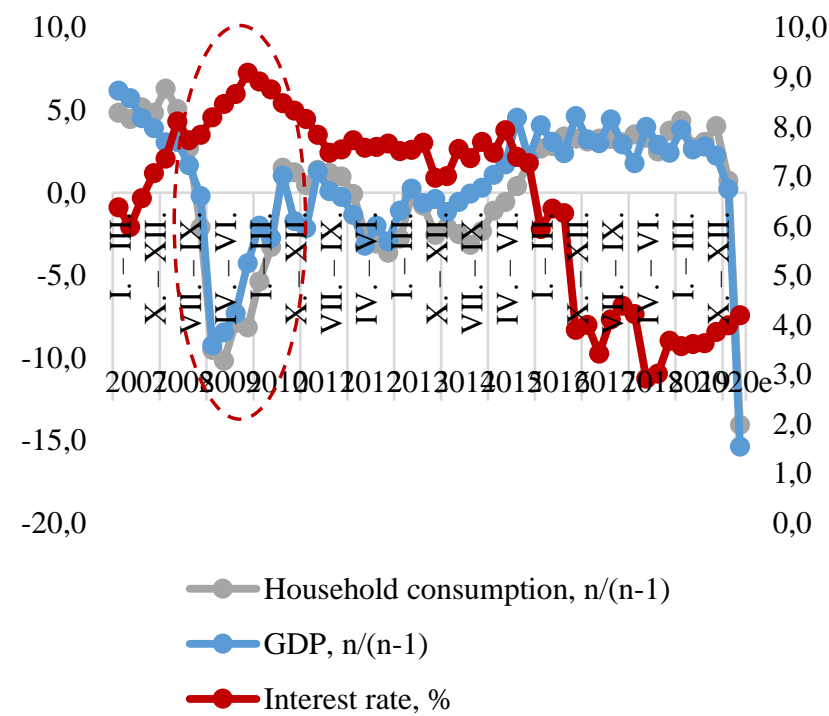

Figure 3. Movements in real GDP, household consumption and interest rate on household loans, growth rate from 2007 to 2020, quarterly level, yoy; Source: Croatian National Bank, Croatian bureau of statistics, author calculation

Figure 3 shows the movement of GDP growth rates, and growth rates of household consumption as the key variable in the structure of GDP measured by the expenditure method, and also the movement of interest rates on household loans. The correlation coefficient between personal consumption and GDP is $r=0.92$. However, observing the correlation coefficient between the movement of interest rates 
on loans to households is $\mathrm{r}=-0.45$, which indicates a negative correlation between the movement of household consumption and interest rates. Figure 3 shows that the Croatian economy reacted differently on those two crisis. In the first crisis, interest rates increased, which had a negative impact on the movement of personal consumption, and consequently on GDP as well. on the other hand, in the second wave of the crisis in 2020there was a continuous decline in interest rates, but this had no effect on consumption growth. The interest rate also tended to decrease in the third quarter of 2020. The effect of consumption neutrality occurred. This phenomenon resulted in one kind of "liquidity trap" in Croatia, where interest rates do not respond to demand.

The dependence of monetary policy

The analysis of CNB's foreign exchange reserves, show the increase of $13.7 \%$ in 2009 crisis in Croatia compared with the world crisis in 2008. Furthermore, that indicates the reaction of the banking system to the financial crisis where interest rate increased and banking system made even higher profit. This fact shows that during the financial crisis in 2008, the Central bank pursued a restrictive monetary policy, eventhough it had elements for expansive monetary policy which would absorb the exogenous shock. However, with a high level of bank capital adequacy, the policy was also disincentive. The Central bank had sufficient resources to meet the import coverage written in list of Central bank's goals. In spite of this, CNB was biased and did not play a positive role in supporting the economic system. In the other words, CNB was influenced by institutionalism.

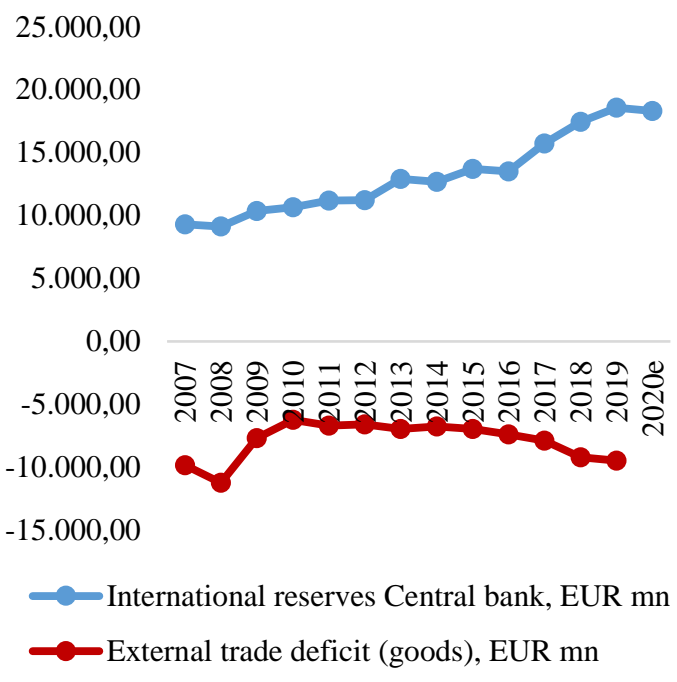

Figure 4. Movements in International reserves of Central bank in EUR mn and movements in external trade goods from 2007 to 2020; Source: Croatian National Bank, author calculation

Notes: at the time of writing this article, there was no full data available for the foreign trade balance

The continuous growth of the foreign exchange reserves of the CNB has led to the fact that the CNB currently has foreign exchange reserves at the level of covering the double trade deficit in croatia from 2019. Even after Croatia entered the European Union, monetary policy did not change. It had a continuous growth of foreign exchange reserves. One of the factors for that fact is the high inflow of foreign tourists, i.e. foreign tourist consumption. The impact of foreign tourism consumption in 2019 was 19.6\% of GDP, both directly and indirectly, while tourism revenue in 2019 amounted 10.6 bn EUR . However, the Croatian Government sent a clear message to the monetary authorities about the new crisis caused by the pandemic, confirming 
that the CNB is ready to respond to the crisis as it has enough liquidity to keep economic activities at pre-crisis level. Pumping liquidity into the system through the low interest rates, as a response to the shock that occurred on the side of aggregate supply and aggregate demand did not vield expected results. An additional factor that accelerated the negative economic trends was the decline in tourist consumption, i.e. the decline in foreign tourists' overnights and also a negative psychological expectations that were present in almost all countries affected by the recession. However, the CNB had a completely different response to the new crisis. The interest rate decreased, despite the uncertainty of the market, what very much differs from the 2009 case, where we witnessed a significant increase in household interest rates.

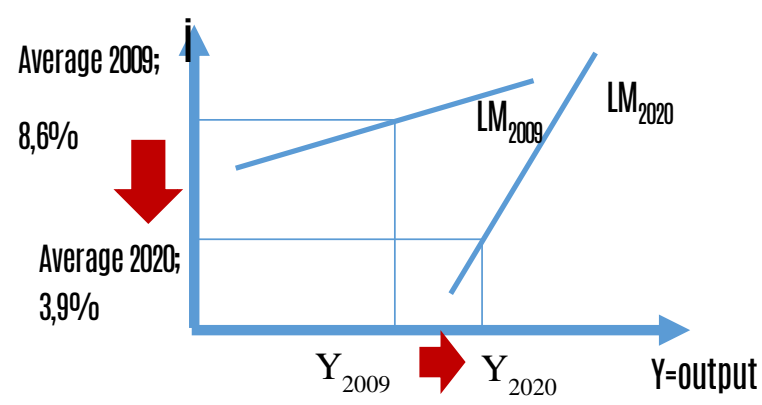

Figure 5. An impact aproximation of interest rate change on total output 2009 us 2020

Figure 5 shows a simulation of the change in the household interest rate on changes in consumption growth. One can see that the LM curves from 2009 and the LM curve from 2020 differ in their elasticity. In 2009, the change in interest rates resulted in a significantly stronger reaction on output growth, while in 2020this case was totally different and the LM curve from 2020 became more inelastic. A small change in interest rate does not significantly affect an output growth. This trend, if continues, could lead to the phenomenon of a "liquidity trap" where interest rates do not have any impact on the growth of demand or output. Mentioned observation is confirmed by H2 hypothesis. The monetary policy is highly dependent on fiscal policy and on government policy. Despite the recession, interest rates are very low, which in 2008 and 2009 was not the case.

The consumption approximated by the movements of turnover in retail trade

Personal consumption as the key component of GDP plays a significant role in the development of economic activities. In the structure of personal consumption, retail trade consumption approximated by retail trade turnover is the most significant contribution variable. The total volume of retail trade in 2019 was over 100.0 bn HRK. From that turnover, a significant share comes from the foreign tourist consumption.

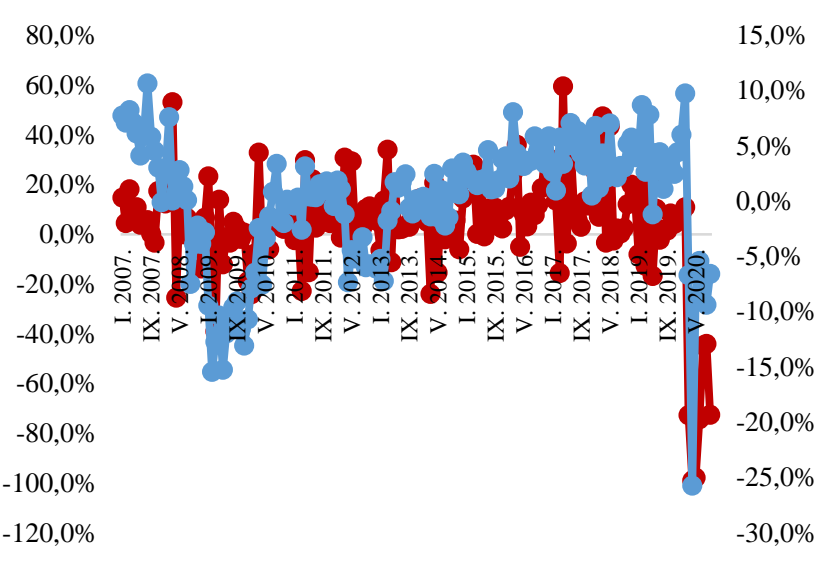

$\longrightarrow$ Overnights rate, $n /(n-1) \longrightarrow$ Retail trade $n /(n-1)$, right scale

Chart 6. Monthly movements in retail trade and foreign

overnights rate, 2007 to 2020 
Chart 6 shows the movement of the retail trade turnover index (year-on-year growth rates) and the growth rate of foreign tourists' overnights. A significant correlation of variables is visible, where the correlation coefficient in the period from January 2007 to September 2020 was $r=0.52$, while at the same time the correlation coefficient after Croatia joined the European Union was very high $\mathrm{r}=0.79$, while after January 2015 to September 2020 was even $r=0.81$. These indicators show an increasingly important impact of tourist consumption in the Croatian economy, which reports an increasing trend over the years. At the same time, the economy is becoming more and more exposed to the elasticity of exogenous shocks. To conculde, a small change in the movement of the number of foreign tourists' overnights, causes significant changes in the movement of consumption in the retail, and thus on total GDP.

Empirical research of the hypothesis H1 and H3
On the basis of conducted tests and analyzes from the previous chapters based on descriptive statistics, in this chapter the hypothesis H1 and H3 will be tested by use of the multiple linear regression model and the software package Eviews 8.0. Based on 165 observations, the author examined the impact of changes in the interest rate, the impact of change in rate of number of foreign tourists' overnights and the rate of change in real net salary on the movement of consumption in retail trade.

H 1: Change in the interest rate on household loans and change of real net salary have no impact on demand growth due to exogenous shock caused in the non-financial sector

H 3: The number of foreign tourists' overnights has an impact on consumption movements in retail trade

Dependent Variable: RETAIL_TRADE

Method: Least Squares

Date: 11/28/20 Time: 18:46

Sample: 1165

Included observations: 165

$\begin{array}{lccc}\text { Variable } & \text { Interest rate } & \text { Net salary } & \text { Overnights } \\ \text { Coefficient } & -0.008366^{* * *} & 0.731951^{* * *} & 0.132611^{* * *} \\ \text { t-Statistic } & {[-4,291267]} & {[4,693904]} & {[-9,470353]}\end{array}$

\section{Model diagnostics}

R-squared

Adjusted R-squared

S.E. of regression

Sum squared resid

Log likelihood

F-statistic

Akaike info criterion
0.533506

0.524814

0.038782

0.242156

3,041151

$6,137598 * * *$

$-3,63776$

International Journal - VALLIS AUREA • Volume 6 • Number 2 • Croatia, December 2020 UDK 338:616; D01 10.2507/IJVA.6.2.2.71 
Schwarz criterion

Hannan-Quinn criter.

Durbin-Watson
$-3,56246$

$-3,60719$

0,868453

Iable 1. Hypothesis test on 165 observations; an impact of interest rate, net salary and foreign tourists' overnights rate on retail trade consumption 2007(January] to 2020(September]

Dependent Variable: RETAIL_TRADE

Method: Least Squares

Date: 11/28/20 Time: 18:53

Sample: 78165

Included observations: 88

Variable

Coefficient

t-Statistic

\section{Model diagnostics}

R-squared

Adjusted R-squared

S.E. of regression

sum squared resid

Log likelihood

F-statistic

Akaike info criterion

Schwarz criterion

Hannan-Quinn criter.

Durbin-Watson
Interest rate

$-0.003348 *$

$[-1,857374]$

0.655667

0.643370

0.027786

0.064854

1,925037

$5,331667^{* * *}$

$-4,284174$

$-4,171568$

$-4,238808$

2,06679
Net salary

$0.423978 * *$

[2,216266]
Overnights

$0,132262 * * *$

$[1,139447]$

Table 2. Hypotesys test on 88 opservations; An impact of interest rate, net salary and foreign tourists' overnights rate on retail trade consumption 2013[july] to 2020(september); E-views, author calculation, * ** , ***, 10\%, 5\%,1\% significance level

The conducted econometric research was based on 165 and 88 observations where the dependent variable is represented by the movement of the turnover rate in retail trade, while the independent variables are interest rate, real net salary growth rate, and the number of foreign tourists' overnights. All independent variables show a high level of reliability and a low level of relation error. All variables in the model have a high level of significance and they are all statistically significant. In the first iteration of 165 observations, it is indicated that the interest rate growth has a very slight effect on retail consumption, while in the second iteration of 88 observations; the same observed variable has an inconsiderable effect on retail consumption. The coefficient of determination is $\mathrm{R2}=0.53$ in the first iteration, while in the second iteration it is above 
$\mathrm{R} 2=0.65$, which means that the model is representative in both cases. Table 2 analysis the period after Croatia joined the European Union, which presents even more representative model. By examining the representativeness of the model, the model is even more representative by approaching the 2020. All independent variables are significant in the model, with the pooled $F$ test also being reliable. The level of significance is below $1 \%$ in both tests at 165 and 88 observations. In Table 1, the DW test showed a low value <2, which indicates the existence of autocorrelation for relation errors. on the other hand, the author indicated by additional testing in the second test by lagging variables that there is no autocorrelation of the first order relations errors. Further confirmation of the absence of autocorrelation problems is shown in table 2 , where at 88 observations with high statistical significance, the independent variables are below $10 \%$. Durbin-Watson test showed a value of $\mathrm{DW}=2.06$ which explains that there is no autocorrelation problem of relation errors.

\section{Conclusion}

In the research author used a descriptive statistics and multiple linear regression model, where the dependent variable is consumption or turnover in retail trade, while the independent variables are the growth rate of interest rates on household loans, real net salary growth rate and foreign tourists' overnights. All independent variables in the model as well as the aggregate model indicate a high level of confidence, $<10 \%$. From the research, it is clear that the economic policies used during the crisis caused by the financial markets and the crisis caused by the pandemic were different. As in any crisis, nor was this one an exception, the financial system plays a key role in stabilization of the economic system. However, when the crisis in the financial markets in 2008 occurred and further affected Croatian economy in 2009, banks played a destabilization role, by raising interest rates in the market while automatically reducing demand and consumption. Such an effect of raising interest rates further pushed Croatia into deeper recession, which lasted until 2014. The mentioned recession lasted from 2009 to 2014 and was the longest recession among all countries in Europe. Although the banking system was strong enough and had an ability to absorb the exogenous shock caused by the financial crisis, mentioned did not happen. They used a contractionary monetary policy, in which banks made above-average profits, while aggregate demand had a continuous decreasing trend. However, the crisis caused by the exogenous shock from non-financial sector started beginning of 2020, and had different response of monetary policy. The monetary policy used in this crisis was a quite opposite compared to 2009. Monetary policy had an expansionary character with a reduction in interest rates, in order to stimulate demand and consumption. In addition to monetary policy, fiscal policy, which was also expansive, had a major impact as well.

Despite of expansive economic policies, the phenomenon, which has not yet recorded in modern economic history, occurred, and that is the crisis of aggregate supply and aggregate demand.

International Journal - valLIS AuREA • Volume 6 • Number 2 • Croatia, December 2020 UDK338:616; 001 10.2507/JJVA.6.2.2.71 
In those situations, the money has more neutral role and is not the only factor driving the economy. Thus, the economic policy performed in 2009 could have mitigate the effects of the exogenous shock. The reason is that the banking system was strong enough, almost as it is now in 2020. The different responses of the Central bank to the crisis indicates the bias and high dependence of the monetary system. An economy based mainly on services and consumption in which the share of tourism revenues is $19.6 \%$ in 2019 in the GDP is extremely elastic to exogenous shocks. Therefore, the lack of a clear strategy of development of Croatian economy will become even larger problem. The strategy should be focused on developing a strong production economy and on self-sufficiency and exports. The high level of elasticity of the economy to foreign tourist consumption, with a continuous decline in domicile consumption caused by depopulation processes, followed by vaguely elaborated strategy, represents a significant challenge for economic policy makers in the upcoming period.

\section{References}

[1] A., Colin Cameron, K., Pravin Trivedi; Microecenometrics: Method and Applications, Cambridge. United Kingdom, 2005

[2] Blanchard, 0., Macroeconomics 5th edition, Pearson, 2008

[3] Croatian central bank, Bulletin No. 165, 165, 177, 188, 205, online editions

[4] Croatian bureau of statistics, retail trade turnover, monthly publications 2007 to 2020 [5] Croatian bureau of statistics, overnights of foreign tursits, monthly publication 2007 to 2020 